Pakadang, S. R., Marsus, I., \& Ihsanawati. (2021). Antibakterial Activity of Endophytic Fungus Isolates of Mangrove Fruit (Sonneratia alba) Against Staphylococcus aureus and Esherichia coli. JURNAL INFO KESEHATAN, 19(1), 55-63. https://doi.org/10.31965/infokes.Vol19/ss1.416

Jurnal Info Kesehatan

Vol. 19, No. 1, June 2021, pp. 55-63

P-ISSN 0216-504X, E-ISSN 2620-536X

DOI: 10.31965/infokes.Vol19Iss1.416

Journal homepage:http://jurnal.poltekeskupang.ac.id/index.php/infokes

\title{
Antibacterial Activity of Endophytic Fungus Isolates of Mangrove Fruit (Sonneratia alba) Against Staphylococcus aureus and Esherichia coli
}

\author{
Sesilia Rante Pakadang ${ }^{1 a^{*}}$, Ismat Marsus ${ }^{2 b}$, Ihsanawati ${ }^{2 c}$ \\ ${ }^{1}$ Department of Pharmacy, Politeknik Kesehatan Kementerian Kesehatan Makassar, Makassar, \\ South Sulawesi, Indonesia. \\ ${ }^{2}$ Faculty of Pharmacy, Universitas Indonesia Timur, Makassar, South Sulawesi, Indonesia. \\ a Email address: mamajassy@gmail.com \\ ${ }^{\mathrm{b}}$ Email address: ismatmarsus@gmail.com \\ c Email address: ihsanawati97@gmail.com
}

Received: 10 May 2020

Revised: 16 April 2021

Accepted: 9 June 2021

\begin{abstract}
Endophytic fungi live and associate in plant tissues and have a mutualistic relationship. Endophytic fungi produce various compounds such as steroids, terpenoids, phenolics, alkaloids which are the same as secondary metabolites from their host plants. The objective of this study is to isolate and identify endophytic fungi from mangrove fruit (Sonneratia alba) and to determine the antibacterial activity of endophytic fungi isolates against the growth of Staphylococcus aureus and Escherichia coli. The type of research is pre-experimental design, one shoot case study. The methods used are isolation, identification and agar diffusion. The pieces of mangrove fruit were disinfected and then cultured on SDA media to grow endophytic fungi isolates. The isolates were cultured repeatedly until pure isolates were obtained. The test of isolate activity against antibacterial was determined by the agar diffusion method with the test material of 2 isolates of endophytic fungi on Nutrient Agar (NA) media. The results showed that the mangrove fruit (Sonneratia alba) produced two isolates of endophytic fungi that could inhibit the growth of Staphylococcus aureus and Escherichia coli. It was concluded that the mangrove fruit culture produced 2 isolates, which are isolate 1 Aspergillus niger and isolate 2 Aspergillus flavus. Isolate 1 and isolate 2 had the potential as antibacterial against the growth of Staphylococcus aureus and Escherichia coli. Isolate 2 was more effective than isolate 1 in inhibiting the growth of Staphylococcus aureus. It is recommended to test the pharmacological and microbiological activity of the findings of isolates 1 and 2 in vivo.
\end{abstract}

Keywords: Mangrove, Antibacterial, Endophytic Fungi.

\section{*Corresponding Author:}

Sesilia Rante Pakadang

Department of Pharmacy, Politeknik Kesehatan Kementerian Kesehatan Makassar, Makassar, South Sulawesi, Indonesia.

Email: mamajassy@gmail.com

(C) The Author(s) 2021. This article is distributed under the terms of the Creative Commons Attribution 4.0 International License (http://creativecommons.org/licenses/by/4.0/), which permits unrestricted use, distribution, and reproduction in any medium, provided you give appropriate credit to the original author(s) and the source, provide a link to the Creative Commons license, and indicate if changes were made. The Creative Commons Public Domain Dedication waiver (http://creativecommons.org/publicdomain/zero/1.0/) applies to the data made available in this article, unless otherwise stated. 


\section{INTRODUCTION}

Microbes are very small living things that can live outside the host body (epiphytic microbes) and live inside the host body (endophytic microbes). Currently, endophytic microbes from plants have been widely studied to determine their potential in treatments such as antibacterial. Endophytic microbes in the form of bacteria, molds and yeasts can be isolated from all plant tissues. The screening results showed that each tissue contained endophytic microbes that differed from one plant to another. The number of isolates obtained from one part of the host plant is frequently very large, but only a few microbes are dominant in one host (Kumala, 2014).

Endophytic fungi are fungi that live internally and associate in plant tissues and have a mutualistic relationship with their host plants as protection against herbivores, insects and pathogens. Endophytic fungi can produce various compounds such as steroids, terpenoids, phenolics, alkaloids that have the potential as antioxidants, anticancer, antibacterial, antiviral, and anti-fungal (Rollando, 2019). The most commonly found bio actives are alkaloids (Kumala, 2014). Some alkaloids can only be produced by plants infected with fungi (Hidayat, et al, 2016).

The existence of mangroves in Indonesia is very abundant in species as identified by Suryono, (2015) finding 10 species in Segara Anakan. Suryono, et al., (2020) found 6 species in Jepara, Central Java. Kezia, et al., (2019) found 10 species in Barru, South Sulawesi. Mangrove fruit has the potential as a source of antioxidants which are proven to contain alkaloids, flavonoids, phenolic compounds, tannins and steroids (Paputungan, et al., 2017). Sonneratia alba extract has antibacterial activity of Streptococcus mutans, Propionibacterium acnes, and Candida albicans. The extract contains secondary metabolites such as alkaloids, phenols, tannins, saponins and flavonoids (Putri, et al., 2016; Kurniawan, et al., 2017). Endophytic fungi isolated from mangrove leaves have the potential to inhibit the growth of Staphylococcus aureus and Escherichia coli (Dwilestari, et al., 2015). Endophytic bacteria from mangroves have the potential as antibacterial against Bacillus sp and Eschericia sp, Staphylococcus aureus and Escherichia coli (Lutfia, 2017; Rismawati, 2018). The objective of the study is to isolate and identify endophytic fungi from mangrove fruit and to determine the antibacterial activity of endophytic fungi isolates against Staphylococcus aureus and Escherichia coli growth. This research is useful for developing the potential of mangroves as medicinal ingredients, especially antibacterial. Finding the types of endophytic fungi isolates on mangrove fruit and proving the activity of the isolates as antibacterial is the novelty of this study.

\section{RESEARCH METHOD}

The type of research used is a pre-experimental design, one shoot case study which was conducted at the Microbiology Laboratory of the University of East Indonesia. The step-by-step procedure was isolation of endophytic fungi, identification of endophytic fungi isolates and in vitro antibacterial activity of endophytic fungi isolates.

Isolation and Purification of Endophytic Fungi were from Mangrove Fruit (Sonneratia alba). All glassware used were sterilized in an oven at $180^{\circ} \mathrm{C}$ for 2 hours. The test material for Mangrove fruit (Sonneratia alba) was taken from the village of Bonto Perak, Pangkajene District, Pangkajene Regency and Islands Province of South Sulawesi. Mangrove fruit was washed with running water for 10 minutes. Then, the surface was sterilized by immersing successively into $75 \%$ alcohol for 1 minute, $5 \%$ sodium hypochlorite $(\mathrm{NaOCl})$ for 5 minutes, and $75 \%$ alcohol for 30 seconds. Furthermore, the mangrove fruit was dried in a sterile petri dish which was given sterile 
filter paper. Mangrove fruit was cut transversely and longitudinally with a size of \pm 1 $\mathrm{cm}$ above a sterile glass object. Then, the pieces of Mangrove Fruit were inoculated on SDA medium (Sabouraud Dextrose Agar with $0.005 \%$ chloram phenicol added) in a petri dish. Incubated at $25^{\circ} \mathrm{C}$ for 5-7 days. The results of the isolation of endophytic fungi growing on SDA medium were purified by re-inoculation of single colonies on SDA media and incubated for 3 days at $25^{\circ} \mathrm{C}$. The incubation results discovered several types of pure mold based on observations of the shape and color of the colonies on SDA medium. Each colony with a different shape or color was re-cultured repeatedly to obtain a pure colony isolate of endophytic fungi.

The results of endophytic fungi isolates were further identified based on macroscopic and microscopic basis. Macroscopic observations included colony shape and color and microscopic observations (shape and size of hyphae, conidia, spores with a microscope). Fungi were identified by matching microscopic specifications with the literature.

Testing the Antibacterial Activity of Mangrove Endophytic Fungi Against Staphylococcus aureus and Escherichia coli. The test bacteria Staphylococcus aureus and Escherichia coli were rejuvenated 1x24 hours and then suspended until a turbidity level was obtained which was equivalent to the Mc Farland standard of 0.5. Mangrove fruit endophytic fungi (Sonneratia alba) which had grown on SDA medium were suspended with sterile distilled water. Blank paper discs were immersed in a suspension of endophytic fungi for 30 minutes and then drained. Sterile Nutrient Agar (NA) medium was poured aseptically into sterile petri dishes and allowed to solidify. Staphylococcus aureus and Escherichia coli suspensions were inoculated on the surface of the NA medium, respectively, using a sterile swab evenly. Paper discs were placed on NA medium that had been inoculated with the test bacteria at approximately the same distance from each other, incubated at $37^{\circ} \mathrm{C}$ for $1 \times 24$ hours. The zone of inhibition formed was measured. The test was administered with 4 times replication. The research has also received a recommendation from the ethics committee of the Health Polytechnic of the Ministry of Health Makassar with the ethics number: 422/KEPK-PTKMKS/V/2019.

\section{RESULTS AND DISCUSSION}

The results of macroscopic and microscopic observations on isolate 1 and isolate 2 can be seen from the following figure:

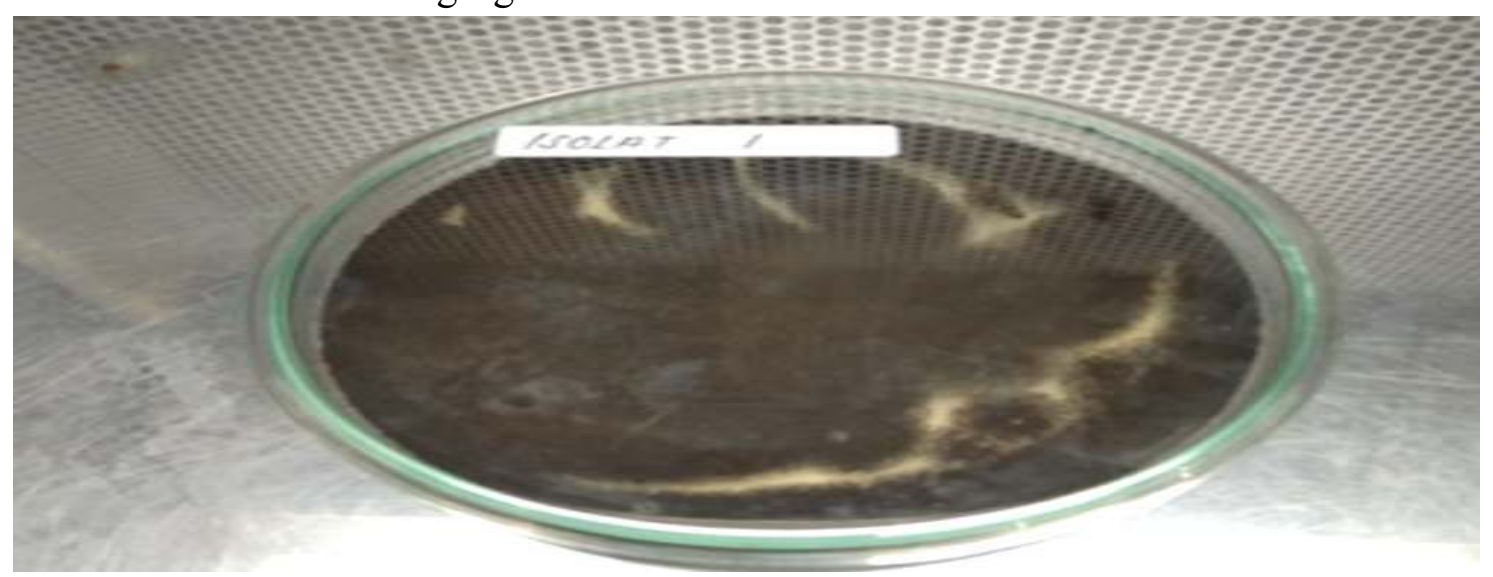

Figure 1. Characteristics of fungal isolate 1 macroscopically. 
Figure 1 shows the macroscopic characteristics of isolate 1, which is the color of the colonies black with white around, the shape of the colonies is round, the distribution is concentrated, the surface of the colonies is rough.

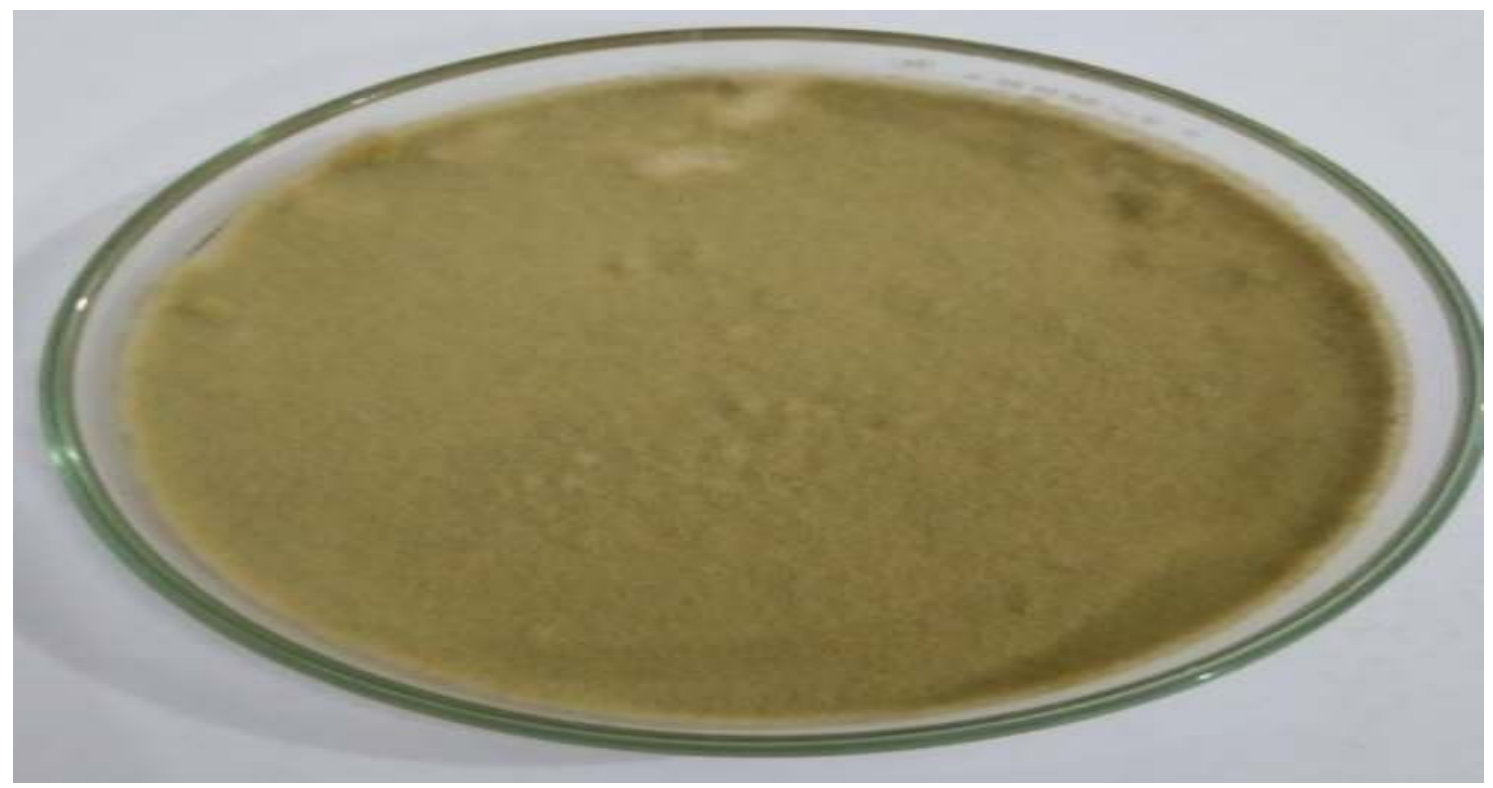

Figure 2. Macroscopic characteristics of fungal isolate 2.

Figure 2 shows the macroscopic characteristics of isolate 2, which is yellowish green colonies, irregular colony shape, spread, smooth colony surface like flour.

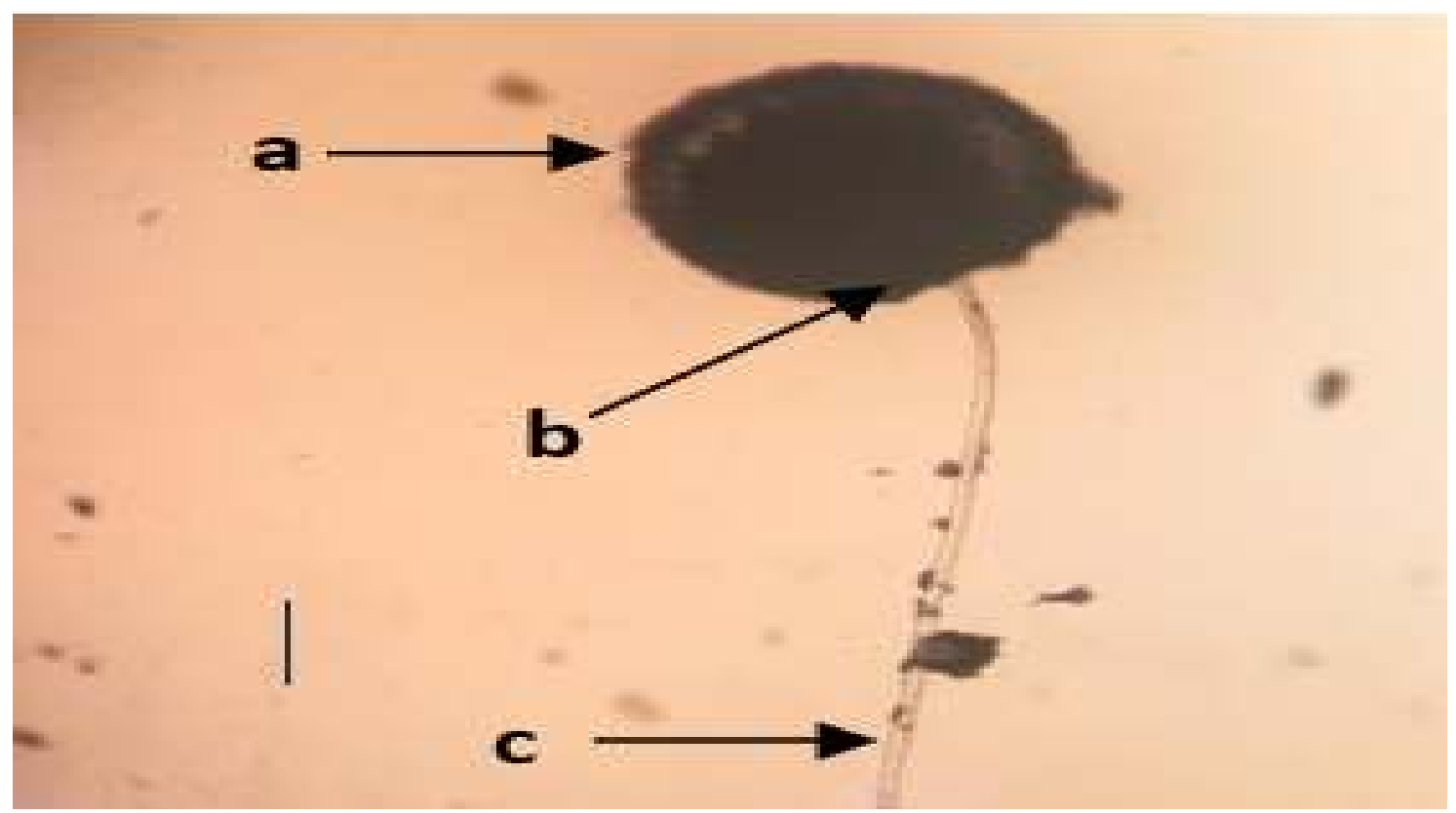

Figure 3. Characteristics of fungal isolate 1 microscopically consisting of: a. Conidia, b. Vesicles and c. Conidiophores.

Figure 3 shows the microscopic characteristics of isolate 1, that is large conidia, round to oval in shape, black in color, conidia in many strands. This fungus has long, thin-walled conidiophores. At the end, it enlarges to form a circle. 


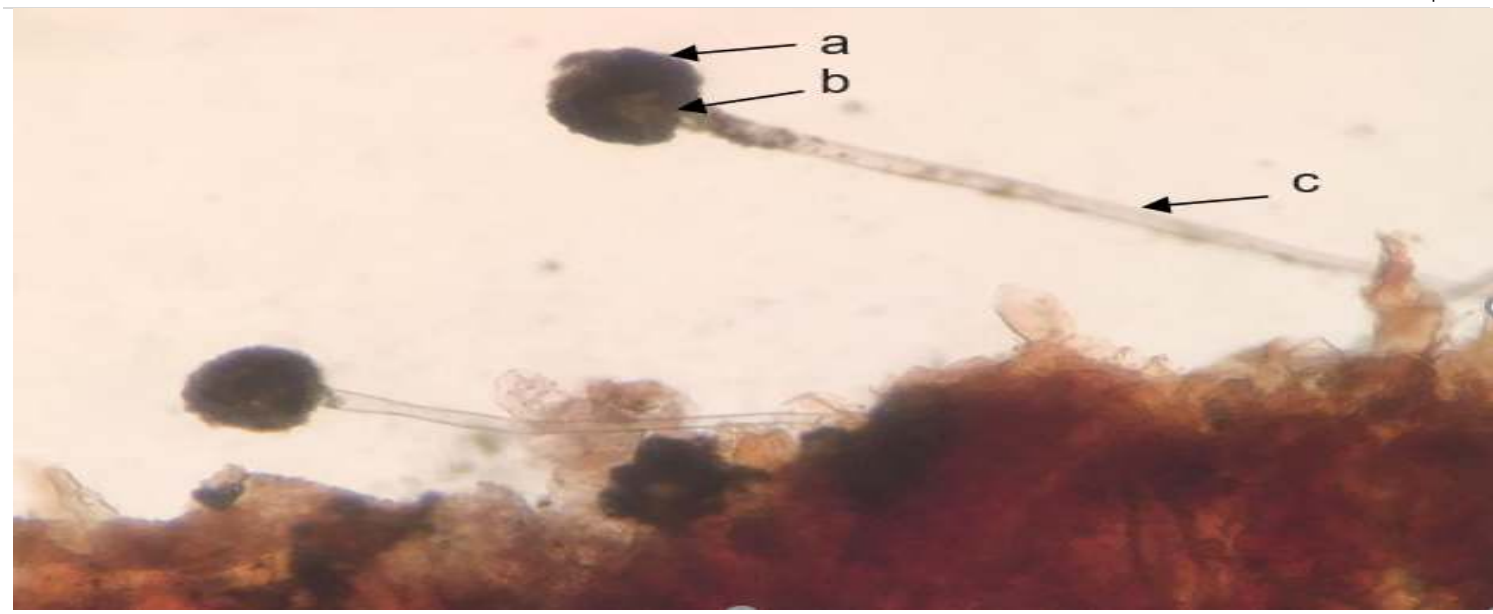

Figure 4. Characteristics of fungal isolate 2 microscopically consisting of: a. Conidia, $b$. Vesicles and c. conidiophores.

Figure 4 shows the microscopic characteristics of isolate 2, which is conidia in many-shaped series. This fungus has thin-walled conidiophores.

Table 1. Results of Measurement of the Growth Inhibition Zone of Staphylococcus aureus and Escherichia coli.

\begin{tabular}{lrrrrrr}
\hline Sample & Treatment & \multicolumn{3}{c}{ Diameter of Bacterial Growth Inhibition } & \multirow{2}{*}{ Average } \\
& & \multicolumn{3}{c}{ Zone (mm) } & \\
\cline { 2 - 6 } & & $\mathbf{1}$ & $\mathbf{2}$ & $\mathbf{3}$ & $\mathbf{4}$ & \\
\hline \multirow{2}{*}{$\begin{array}{l}\text { Staphylococcus } \\
\text { aureus }\end{array}$} & Isolate 1 & 9,5 & 9,5 & 10 & 10 & 9,75 \\
\cline { 2 - 6 } $\begin{array}{l}\text { Escherichia } \\
\text { coli }\end{array}$ & Isolate 2 & 14,5 & 13,25 & 12 & 12,25 & 13 \\
\hline & Isolate 1 & 10 & 9,75 & 10,5 & 10 & 10,06 \\
\hline
\end{tabular}

The distribution of mangrove plants in Indonesia is very large, for intanstance, in Barru Regency, South Sulawesi, 7 species were found (Saru, et al., 2019) and in Rote Ndao, East Nusa Tenggara, 11 species were found (Ngoma, et al., 2020). It provides an opportunity to utilize mangrove species for treatment, for example as an antibacterial. The use of mangroves has been examined in the form of extracts, but isolating endophytic fungi from mangrove fruit is a more efficient way of utilization. The use of endophytic microbes as antibacterial has been performed on other plant species such as katokkon chili (Rolando, 2019), cucumber (Yuanwar and Ainy, 2019), gotu kola (Hidayat, et al., 2018), secang wood (Amirullah, et al., 2019); areca nut (Nuryanti and Astuti, 2019), and beluntas leaves (Setiawan and Musdalipah, 2018).

The results of the study found two pure isolates of endophytic fungi from mangrove fruit (Sonneratia alba). The colony was identified as Aspergillus niger which is in accordance with Hidayat's, et al., (2018) statement that black colonies are a marker of the presence of Aspergillus niger. On microscopic observation of isolate 1, conidia were found to be large, round to oval in shape, black in color, conidia in series to be numerous. This fungus has long, thin-walled conidiophores. At the end, it enlarges to form a circle. Based on these characteristics, the isolate was suspected to be the fungus Aspergillus niger. It is in accordance with the statement of Gandjar (2000) that the characteristic of Aspergillus niger is that the conidia heads are black, round in shape, and tend to split into columns in old colonies. The stipe of conidiophores is smoothwalled, hyaline in color, but may also be brownish. The vesicles are spherical to 
semicircular, and $50-100 \mathrm{~m}$ in diameter. Conidia are spherical to semi-spherical measuring 3.5-5.0 m, brown in color and have irregular ornamentation in the form of protrusions and spines. The findings of Aspergillus $s p$ isolates from mangrove plant cultures were also identified (Mukhlis, et al., 2018).

Observations on isolate 2 were macroscopically in the form of yellowish green colonies, irregular colony shape, spread, smooth colony surface like flour. Microscopic observations in the form of many conidia in series. This fungus has thin-walled conidiophores. These characteristics are thought to be the same as those of the flavus fungus. It is based on Amaliyah's (2017) statement that colonies of Aspergillus flavus generally grow rapidly and reach a diameter of $6-7 \mathrm{~cm}$ in $10-14$ days. This mold has a yellow initial color which will turn greenish yellow or brown with an inverted golden color or colorless while the old colonies have a dark green color. Gandjar (2000), explained that the typical conidia head is round, then splits into several columns, and is yellowish green to yellowish dark green. Conidiophores are hyaline, leathery, and can reach a length of $1.0 \mathrm{~mm}$ (some are up to $2.5 \mathrm{~mm}$ ). Vesicles are round to semi-spherical, conidia are round to semi-spherical (Sumampouw, 2019). Khalimah and Ainy (2019), have also isolated 3 isolates from mangroves and have even identified secondary metabolites from Aspergillus sp isolates as flavonoids, tannins and saponins.

The results of endophytic fungi isolates from mangrove fruit were obtained after antibacterial testing was performed against Staphylococcus aureus and Escherichia coli. The results showed that there were inhibition zones of isolates 1 and 2 of endophytic fungi of mangrove fruit against the growth of Staphylococcus aureus and Escherichia coli. In isolate 1, endophytic fungi of mangrove fruit which was examined on Staphylococcus aureus test bacteria had an average inhibition zone diameter of $9.75 \mathrm{~mm}$ and for Escherichia coli had an average inhibition zone diameter of $10.06 \mathrm{~mm}$. For isolates 2 endophytic fungi of mangrove fruit tested on Staphylococcus aureus had an average inhibition zone of $13 \mathrm{~mm}$ and for Escherichia coli had an average inhibition zone of 10.03. These data indicate that endophytic fungi that grow on mangrove fruit (Sonneratia alba) can inhibit the growth of Staphylococcus aureus and Escherichia coli. The endophytic fungi activity of mangrove fruit is in line with the activity of mangrove plant extracts as antibacterial against several bacteria, including Staphylococcus aureus and Escherichia coli (Dwilestari, et al., 2015). This antibacterial potential is caused by the content of secondary metabolites present in plants such as steroids, terpenoids, phenolics, and alkaloids (Rollando, 2019; Kumala, 2014; Hidayat, et al., 2016). Endophytic fungi isolated from other coastal plants such as mangrove roots (Rhizophora apiculate) also produced 2 isolates of black fungus and white fungus that have potential as antibacterial Staphylococcus aureus and Escherichia coli (Kartika, et al., 2014). Posangi and Bara (2014) found 2 isolates identified as Aspergillus sp. and Acremonium $s p$ which functions as an antibacterial for Staphylococcus aureus and Escherichia coli. Mukhlis, et al., (2018) found 3 types of isolates, which are Fusarium sp, Penicillium sp and Aspergillus sp which have the potential to inhibit the growth of Staphylococcus aureus and Escherichia coli.

Isolate 1 was identified as Aspergillus niger (colored black) and isolate 2 was identified as Aspergillus niger (colored white/beige). The results of the measurement of the diameter of the inhibition zone of isolates 1 and 2 of endophytic fungi against the growth of Staphylococcus aureus and Escherichia coli were analyzed by SPSS. The normality test shows a sig value of 0.024 which means that there is data that is not normally distributed. The homogeneity test shows a sig value of $0.045<0.05$, which means the data is not homogeneous. Hence, the next analysis was performed by the Kruskal Wallis non-parametric test and continued with Mann Whitney. Kruskal Wallis 
Pakadang, S. R., Marsus, I., \& Ihsanawati. (2021). Antibakterial Activity of Endophytic Fungus Isolates of Mangrove Fruit (Sonneratia alba) Against Staphylococcus aureus and Esherichia coli. JURNAL INFO KESEHATAN, 19(1), 55-63. https://doi.org/10.31965/infokes.Vol19/ss1.416

| 61

test showed a sig value of $0.005<0.05$, which means that there was a difference in the effect of isolate 1 and isolate 2 in inhibiting the growth of Staphylococcus aureus and Escherichia coli. Further analysis with Mann Whitney showed differences in the effectiveness of endophytic fungi isolates as antibacterial as follows: The effectiveness of isolate 1 against Staphylococcus aureus and Escherichia coli was not significantly different, the effectiveness of isolate 1 and isolate 2 was not significantly different against Escherichia coli and isolate 2 was more effective than isolate 1 in inhibit the growth of Staphylococcus aureus. The effectiveness of isolate 2 which was identified as Aspergillus flavus was better than isolate 1 which was identified as Aspergillus niger in line with research (Kasi, et al., 2015) which concluded that white mycelium endophytic fungi had a better antibacterial effect than black mycelium endophytic fungi and positive controls.

The findings of endophytic fungi isolates in this study have the potential for further testing of pharmacological activities. The discovery of endophytic fungi isolates can further develop the use of Sonseratia alba without having to harvest this mangrove species every time.

\section{CONCLUSION}

Mangrove fruit (Sonneratia alba) produced two isolates of endophytic fungi, which were Isolate 1 suspected of Aspergillus niger and Isolate 2 suspected of Aspergillus flavus. Isolate 1 and isolate 2 of endophytic fungi from Mangrove Fruit (Sonneratia alba) have the potential as antibacterial against the growth of Staphylococcus aureus and Escherichia coli. Isolate 2 was more effective than isolate 1 in inhibiting the growth of Staphylococcus aureus. It is recommended to continue this research to test the pharmacological and microbiological activities of isolates 1 and 2 in vivo.

\section{REFERENCES}

Amaliyah, N. (2017). Penyehatan Makanan Dan Minuman-A. Jakarta: Deepublish.

Amirullah, A., Sartini, S., \& Nainu, F. (2019). Fungi Endofit dari Tanaman Secang (Caesalpinia sappan L) Sebagai Penghasil Senyawa Antioksidan. Jurnal Farmasi Galenika (Galenika Journal of Pharmacy)_(e-Journal), 5(1), 26-32. doi: https://doi.org/10.22487/j24428744.2019.v5.i1.12013

Dwilestari, Awaloei, H., Posangi, J., \& Bara, R. (2015). Uji Efek Antibakteri Jamur Endifit Pada Daun Mangrove Sonneratia alba Terhadap Bakteri Uji Staphylococcus Aureus Dan Escherichia Coli. eBiomedik, 3(1), 394-398.

Gandjar, I., \& Rifai, M. A. (2000). Pengenalan kapang tropik umum. Jakarta: Yayasan Obor Indonesia.

Hidayat, N., Wignyanto, Sumarsih, S., \& Putri, A. I. (2016). Mikologi Industri. Malang: Universitas Brawijaya Press.

Hidayat, N., Meitiniarti, I., Yuliana N. (2018). Mikroorganisme dan Pemanfaatannya. Malang: Universitas Brawijaya Press.

Hidayat, M., Mufidah, M., \& Rante, H. (2018). Isolasi Dan Karakterisasi Molekuler Mikroba Endofit Tanaman Pegagan (Centella asiatica L.) Sebagai Penghasil Antimikroba. Majalah Farmasi Dan Farmakologi,22(2), 56-60. doi: https://doi.org/10.20956/mff.v22i2.5702

Kartika, R., Bodhi, W., Kepel, B., \& Bara, R. (2014). Uji daya hambat jamur endofit akar bakau Rhizophora apiculata terhadap bakteri Staphylococcus aureus dan Escherichiae coli. eBiomedik, 2(1). 
Kasi, Y. A., Posangi, J., Wowor, P. M., \& Bara, R. (2015). Uji efek antibakteri jamur endofit daun mangrove Avicennia marina terhadap bakteri Uji Staphylococcus aureus dan Shigella dysenteriae. eBiomedik, 3(1), 112-117.

Kezia, E., Nurkin, B., Bachtiar, B., Millang, S., Restu, M., \& Larekeng, S. H. (2019). Potential of mangrove stands carbon deposits in the North Part Pannikang Islands, Barru Regency, South Sulawesi Province. IOP Conference Series: Earth and Environmental Science, 343(1), p.012060. doi: https://doi.org/10.1088/17551315/343/1/012060

Khalimah, D., \& Ainy, E. Q. (2019). Isolasi fungi endofit daun mangrove Avicennia marina dan uji aktivitasnya sebagai antifungi terhadap Candida albicans ATCC. Symposium of Biology Education (Symbion). 2 , 298-305. doi: https://doi.org/10.26555/symbion.3551

Kumala, S. (2014). Mikroba Endofit Pemanfaatan Mikroba Endofit dalam Bidang Farmasi. Jakarta: PT. ISFI Penerbitan.

Kurniawan, D., Muliawan, A., \& Kuspradini, H. (2017). Efektivitas Ekstrak Buah Sonneratia Alba Terhadap Aktivitas Bakteri. Jurnal Harpodon Borneo, 10(1), 112.

Lutfia, A. (2017). Skrining dan Karakterisasi Bakteri Endofitik dari Sonneratia alba (Sonneratiaceae) Sebagai Penghasil Antibiotika. Skripsi. Fakultas Matematika dan Ilmu Pengetahuan Alam, Universitas Andalas.

Mukhlis, D. K., Rozirwan, R., \& Hendri, M. (2018). Isolasi dan aktivitas antibakteri jamur endofit pada mangrove Rhizophora apiculata dari kawasan mangrove Tanjung Api-Api Kabupaten Banyuasin Sumatera Selatan. Maspari Journal, 10(2), 151-160.

Ngoma, R. B., Hendrik, A. C., \& Ballo, A. (2020). Keanekaragaman Mangrove dan Pemanfaatannya di Desa Daiama, Kecamatan Landu Leko, Kabupaten Rote Ndao, Propinsi Nusa Tenggara Timur. SIMBIOSA, 9(2), 118-128. doi: https://doi.org/10.33373/sim-bio.v9i2.2498

Nuryanti, S., \& Astuti, R. (2019). Potensi Fungi Endofit Biji Pinang Sebagai Antibakteri Terhadap Escherichia coli dan Salmonella thypi. Green Medical Journal, 1(1), 87-96. doi: https://doi.org/10.33096/gmj.v1i1.23

Paputungan, Z., Wonggo, D., \& Kaseger, B. E. (2017). Uji Fitokimia Dan Aktivitas Antioksidan Buah Mangrove Sonneratia alba Di Desa Nunuk Kecamatan Pinolosian Kabupaten Bolaang Mongondow Selatan Sulawesi Utara. Media Teknologi Hasil Perikanan, 5(3), 96-102. doi: https://doi.org/10.35800/mthp.5.3.2017.16866

Posangi, J., \& Bara, R. A. (2014). Analisis aktivitas dari jamur endofit yang terdapat dalam tumbuhan bakau Avicennia marina di Tasik Ria Minahasa. Jurnal Pesisir dan Laut Tropis, 2(1), 30-38. doi: https://doi.org/10.35800/jplt.2.1.2014.7345

Putri, R. R., Hasanah, R., \& Kusimaningrum, I. (2016). Uji aktivitas antibakteri dan Uji fitokimia ekstrak daun mangrove Sonneratia alba. J. Aquawarman, 2(1), 43-50.

Rismawati. (2018). Identifikasi Bakteri Endofit Daun Mangrove Api-Api Putih Avicennia marina) dan Potensinya Menghasilkan Senyawa Anti Mikroba. Skripsi. Fakultas Sains dan Teknologi, UIN Alauddin. Makassar.

Rollando. (2019). Senyawa Antibakteri Dari Fungi Endofit. Malang: CV Seribu Bintang.

Saru, A., Idrus, R., \& Ilham, M. (2019). The Mangrove Ecosystem Potential For Educational Tour Development Around Pond Education Of Hasanuddin University (UNHAS) In Mallusetasi District, Barru Regency. Jurnal Ilmu Kelautan Spermonde, 5(2), 70-76. doi: https://doi.org/10.20956/jiks.v5i2.8934 
Pakadang, S. R., Marsus, I., \& Ihsanawati. (2021). Antibakterial Activity of Endophytic Fungus Isolates of Mangrove Fruit (Sonneratia alba) Against Staphylococcus aureus and Esherichia coli. JURNAL INFO KESEHATAN, 19(1), 55-63. https://doi.org/10.31965/infokes.Vol19/ss1.416

Setiawan, M. A., \& Musdalipah, M. (2018). Uji Daya Hambat Antibakteri Fungi Endofit Daun Beluntas (Pluchea indica (L.) Less.) Terhadap Bakteri Streptococcus mutans. Jurnal Mandala Pharmacon Indonesia, 4(1), 53-60. doi: https://doi.org/10.35311/jmpi.v4i1.24

Sumampouw, O. J. (2019). Mikrobiologi Kesehatan. Yogyakarta: Deepublish.

Suryono, C. A. (2015). Ekologi Mangrove Di Segara Anakan Ditinjau dari Aspek: Kelimpahan dan Distribusi. Jurnal Kelautan Tropis, 18(1), 20-27. doi: https://doi.org/10.14710/jkt.v18i1.510

Suryono, S., Taufiq-SPJ, N., Pratikto, I., \& Ario, R. (2020). Sebaran Mangrove di Desa Bumiharjo Kecamatan Keling Kabupaten Jepara. Buletin Oseanografi Marina, 9(2), 117-124. doi: https://doi.org/10.14710/buloma.v9i2.29067

Yuanwar, B. D., \& Ainy, E. Q. (2019). Isolasi fungi endofit kulit mentimun (Cucumis sativus L.) dan evaluasi aktivitas penghambatannya terhadap pertumbuhan Candida albicans ATCC 10231. Symposium of Biology Education (Symbion). 2, 306-315. doi: https://doi.org/10.26555/symbion.3552 